\title{
Foliar chemical composition of two oak species grown in a free-air enrichment system with elevated $\mathrm{O}_{3}$ and $\mathrm{CO}_{2}$
}

\author{
Cong Shi ${ }^{\text {a }}$, Mitsutoshi KitaO ${ }^{b}$, Evgenios AgathoKleous ${ }^{\text {a }}$, Makoto WatAnABE ${ }^{c}$ \\ Hiroyuki TOBITA $^{\text {b }}$, Ken'ichi YAZAKI ${ }^{\text {b }}$, Satoshi KITAOKA ${ }^{\text {b }}$ and Takayoshi KOIKE ${ }^{\text {a, }}{ }^{\mathrm{c}}$ \\ ${ }^{a}$ Silviculture and Forest Ecological Studies, Hokkaido University, Sapporo 060-8689, Japan \\ ${ }^{\mathrm{b}}$ Forestry and Forest Products Research Institute, Tsukuba 305-8687, Japan \\ ${ }^{\mathrm{c}}$ Tokyo University of Agriculture and Technology, Tokyo 183-8509, Japan
}

\begin{abstract}
Ground level ozone $\left(\mathrm{O}_{3}\right)$ is rapidly increasing in Asia and penetrates plants via stomata. Atmospheric carbon dioxide $\left(\mathrm{CO}_{2}\right)$ has also been increasing in global and in short term may promote plant growth via photosynthetic enhancement. Oaks are representative deciduous broadleaved trees native to northeastern Asia. In this study, we focused on the effects of elevated $\mathrm{O}_{3}$ and/or $\mathrm{CO}_{2}$ on leaf nutrients status (phosphorous, nitrogen, potassium, magnesium, etc.) of two oak species: Konara oak (Quercus serrata) and Mizunara oak (Quercus mongolica var. crispula) to assess their function. We investigated foliar starch and sugar contents and nutrients composition of leaves of 2-year-old oak seedlings grown under elevated $\mathrm{O}_{3}$ and/or $\mathrm{CO}_{2}$ in a free air enrichment system. From elements concentration, nitrogen and magnesium may become the major indices in assessing the $\mathrm{O}_{3}$ effects on these species, and investigation of both of them would be of use in field studies to discriminate $\mathrm{O}_{3}$ and $\mathrm{CO}_{2}$ effects, especially under the projected elevated $\mathrm{CO}_{2}$ levels.
\end{abstract}

Key words: Elevated ozone, Elevated carbon dioxide, Free-air enrichment, Nutrient elements, Oak.

\section{Introduction}

Recently, tropospheric ozone or ground level ozone $\left(\mathrm{O}_{3}\right)$ is continuously increasing in northeast Asia and reduces vigor and health of forests (e.g. Izuta, 2006; Takigawa et al., 2009; Yamaguchi et al., 2011; Koike et al., 2013). In Asian countries, the emission of precursors for $\mathrm{O}_{3}$ had been increasing and it is expected to continually increase in the foreseeable future (Solberg et al., 2005; Karnosky et al., 2007; Ohara et al., 2007; Watanabe et $a l ., 2007$ ). As a result, $\mathrm{O}_{3}$ in Asia, including China and Japan, will be also increasing for at least several decades (e.g. Koike et al., 2013). Thus, $\mathrm{O}_{3}$ has been regarded as one of the most serious environmental stresses for plants (Matyssek et al., 2012; Agathokleous et al., 2015), concerning with forest decline and tree dieback in East Asia (Izuta and Nakaji, 2003; Izuta, 2006; Watanabe et al., 2005). O $\mathrm{O}_{3}$ concentration usually shows the highest value from spring to summer in northeast Japan (Yamaji et al., 2006).

On the other hand, atmospheric carbon dioxide $\left(\mathrm{CO}_{2}\right)$ concentration has been yearly increasing and reached to nearly $400 \mu \mathrm{mol}$ $\mathrm{mol}^{-1}$ from May 2013 (NOAA, 2014). Elevated $\mathrm{CO}_{2}$ concentration $\left(\mathrm{eCO}_{2}\right)$ may have combined effects with elevated $\mathrm{O}_{3}$ concentration $\left(\mathrm{eO}_{3}\right)$ on the growth and photosynthetic capabilities of representative forest species in Japan (e.g. Matsumura et al., 2005). It is said that $\mathrm{eCO}_{2}$ can someway compensate the negative effect of high $\mathrm{O}_{3}$ on growth of deciduous trees related to stomatal closure (Watanabe et al., 2010; Koike et al., 2012). Some researches indeed were carried out on foliar chemical compositions

Received; June 4, 2014.

Accepted; October 22, 2015.

${ }^{\dagger}$ Corresponding Author: tkoike@for.agr.hokudai.ac.jp

DOI: 10.2480/agrmet.D-14-00018 in $\mathrm{eO}_{3}$ or $\mathrm{eCO}_{2}$; most of them however mainly focus on the concentrations of nitrogen $(\mathrm{N})$ and carbon (C) (e.g. Baldantoni et al., 2011). Therefore, few data are available for understanding $\mathrm{eO}_{3}$ and/or $\mathrm{eCO}_{2}$ effects on woody species in terms of specific nutrient analysis, even though many physiological and morphological functions are directly regulated by nutrients (e.g. Kohno et al., 2005; Izuta, 2006; Kitao et al., 2015) .

Konara (Quercus serrata: Qs) and Mizunara (Q. mongolica var. crispula: $Q m$ ) are deciduous oaks, economically and ecologically important in the rural region of Japan (Maruyama and Miyaura, 2007; Watanabe et al., 2014). These are ectomycorrhizal (ECM) trees (e.g. Oh et al., 1995) and flush 1 to 2 times their shoots in the growing season. Although oaks are regarded as $\mathrm{O}_{3}$ stress tolerant species among 18 woody species in Japan, they are declining in southern Japan (Kohno et al., 2005). Among the 18 species, $Q s$ is relatively sensitive to $\mathrm{O}_{3}$ compared with $Q m$ (Yamaguchi et al., 2011) .

At $\mathrm{eCO}_{2}$, stomatal conductance (Gs) is reduced, accompanied with an enhanced photosynthetic rate because plants do not need widely open stomata for getting $\mathrm{CO}_{2}$ (Paoletti and Grulke, 2005; Fares et al., 2014). A reduction in Gs would decrease xylem sap flow via a reduced transpiration. Conversely, $\mathrm{eO}_{3}$ induces a reduction in Gs but accompanied with a decline in photosynthetic function (Paoletti and Grulke, 2005; Hoshika et al., 2012; 2013). It has also been suggested that $\mathrm{eO}_{3}$ can affect carbohydrate metabolism and hence to reduce their contents (Slid et al., 2002); yet remains unclear. On the contrary, carbohydrates (e.g. starch and sugar) contents may be increased under $\mathrm{eCO}_{2}$ treatment mainly due to the elevated starch level (e.g. Keutgen and Chen, 2001; Koike, 2006).

In general, leaf mineral content is determined by the balance between influx via xylem and phloem, and efflux via phloem (e.g. Larcher, 2003). In this context, $\mathrm{eO}_{3}$ and/or $\mathrm{eCO}_{2}$ would modify 
leaf mineral contents such as macro-elements: phosphorous $(\mathrm{P})$, nitrogen $(\mathrm{N})$, potassium $(\mathrm{K})$, magnesium $(\mathrm{Mg})$ and calcium (Ca) as well as micro-elements: manganese $(\mathrm{Mn})$ via the changes in xylem flow and phloem loading. For instance, concentrations of $\mathrm{K}, \mathrm{Mg}$ and $\mathrm{Mn}$ in leaves are significantly increased under $\mathrm{eCO}_{2}$ (Fangmeier et al., 2002) whereas photosynthetic performances will be depressed under $\mathrm{eO}_{3}$ exposure with decreasing of $\mathrm{Mg}$ and Mn (Saul, 1964; Paoletti et al., 2002).

From these, it is hypothesized that $\mathrm{eO}_{3}$ and/or $\mathrm{eCO}_{2}$ may alter the balance of water-soluble nutrients such as $\mathrm{K}, \mathrm{Mg}, \mathrm{Mn}$, through change in Gs. It was also expected that foliar nutrients balance in 2 oaks would be altered due to $\mathrm{eO}_{3}$ effects. Especially, $Q s$ may have big changes in some nutrient elements due to relatively higher $\mathrm{O}_{3}$ sensitivity as compared with $Q m$ (Yamaguchi et al., 2011).

To address these hypotheses, we focused on the nutrients composition and also carbohydrate accumulation in 2 oak species grown under free-air enrichment of $\mathrm{eO}_{3}$ and/or $\mathrm{eCO}_{2}$. Based on findings of the changes in starch and sugar as well as 6 nutrient elements ( $\mathrm{P}, \mathrm{N}, \mathrm{K}, \mathrm{Mg}, \mathrm{Mn}$ and $\mathrm{Ca}$ ), we discuss the representative elements and starch in relation to growth traits in the 2 oaks grown under $\mathrm{eO}_{3}$ and/or $\mathrm{eCO}_{2}$ and hence investigate indices for understanding the effects of $\mathrm{eO}_{3}$ and $\mathrm{eCO}_{2}$ in these oaks in such future environmental conditions.

\section{Materials and methods}

\subsection{Plant Materials}

Two-year-old seedlings of Konara oak (Quercus serrata Murray: $Q s$ ) and Mizunara oak (Quercus mongolica Fisch. ex Ledeb. var. crispula (Blume) Ohashi: $Q m$ ) were obtained from near Tsukuba, and planted in the nursery (soil $\mathrm{pH}=$ about 5.5) of Forestry and Forest Products Research Institute (FFPRI) in Tsukuba, near Tokyo. They were planted at $50 \mathrm{~cm}$ interval from each other. Generally, these deciduous oak species cover most parts of Japan and their varieties are also dominant in cool temperate regions of China and Korean peninsula (Menitsky, 2005). Konara oak is one of the most common and widely distributed oak tree species in East Asian temperate forests; Mizunara oak is also typical species in the mixed broadleaf/conifer forests native to the cool-temperate of northeastern Asia (Nakashizuka and Iida, 1995).

\subsection{Free-air enrichment system}

The free-air enrichment system was located at the experimental nursery of FFPRI in Tsukuba, near Tokyo, Japan $\left(36^{\circ} 00^{\prime} \mathrm{N}\right.$, $140^{\circ} 08^{\prime} \mathrm{E}, 20 \mathrm{~m}$ a.s.l.). The mean annual precipitation and temperature was $1396 \mathrm{~mm} \mathrm{yr}^{-1}$ and $14.0^{\circ} \mathrm{C}$. The system was installed with 4 factorial combination treatments of elevated $\mathrm{O}_{3}\left(\mathrm{eO}_{3}\right)$ and/or elevated $\mathrm{CO}_{2}\left(\mathrm{eCO}_{2}\right)$ as follow: ambient (control), eO $\mathrm{e}_{3}$, $\mathrm{eCO}_{2}, \mathrm{eO}_{3}$ and $\mathrm{eCO}_{2}\left(\mathrm{e}\left(\mathrm{O}_{3}+\mathrm{CO}_{2}\right)\right.$ ) (each frame size was $3.0 \mathrm{~m} \times$ $3.0 \mathrm{~m} \times 2.0 \mathrm{~m}$ ) constructed by DALTON Ltd. Co. (Tokyo). Totally 12 plots were installed with 3 replicates for each treatment. Elevated $\mathrm{O}_{3}\left(\mathrm{eO}_{3}\right)$ concentration was 2 times higher than the ambient level and $\mathrm{eCO}_{2}$ concentration was controlled at about 550 $\mu \mathrm{mol} \mathrm{mol}{ }^{-1}$ in order to simulate 2060 projections (IPCC, 2007). Mean 10h daytime (from 7:00-17:00) $\mathrm{O}_{3}$ concentration during the experimental period was $30.2 \pm 0.4$ and $52.2 \pm 2.1 \mathrm{nmol} \mathrm{mol}^{-1}$ (mean $\pm \mathrm{SD}$ ) for ambient and $\mathrm{eO}_{3}$, respectively. Meanwhile, mean 10h daytime (from 7:00-17:00) $\mathrm{CO}_{2}$ concentration during the experiment period was $377 \pm 2.9$ and $546 \pm 21.3 \mu \mathrm{mol} \mathrm{mol}^{-1}$ for ambient and $\mathrm{eCO}_{2}$, respectively (Kitao et al., 2015).

$\mathrm{O}_{3}$ was generated from an ozone generator (Model PZ2A; Kofloc, Kyoto, Japan) and $\mathrm{eO}_{3}$ (2 times of ambient) was released from a tubing system suspended throughout the plot. $\mathrm{CO}_{2}$ was provided by AIR WATER INC. (Osaka, Japan) from liquid $\mathrm{CO}_{2}$. An $\mathrm{O}_{3}$ analyzer (Model EG-3000F; Ebara Jitsugyo Co. Ltd., Kanagawa, Japan) and an $\mathrm{O}_{3}$ monitor (Model 205; 2B Technologies, Boulder, Colorado) were used to control and monitor the $\mathrm{O}_{3}$ concentration. In addition, $\mathrm{CO}_{2}$ concentration was monitored with both a Carbon Dioxide Probe (Model GMP343; Vaisala, Helsinki, Finland) and an infrared $\mathrm{CO}_{2}$ analyzer (Model LI-820; LI-COR Inc., Lincoln, Nebraska) (Kitao et al., 2015). The 2 oak seedlings were grown for one growing season, from beginning of April to the end of October in 2011 under the treatment combinations. Each plot had 6 seedlings of each oak species (i.e. $6 \mathrm{Qs}$ and $6 \mathrm{Qm}$, totally 12 seedlings).

\subsection{Measurements}

After 2 to 4 months' treatment with $\mathrm{eO}_{3}$ and $/$ or $\mathrm{eCO}_{2}, 3^{\text {rd }}$ or $4^{\text {th }}$ leaves (counted from the shoot tip) were sampled. As a shoot developmental patterns, either $Q m$ or $Q s$ was classified as a flush type shoot growth (e.g. Kikuzawa, 1983). However, oaks normally flush 2-3 times in one growing season. Therefore, first-flush leaves in May and the first- and second-flush leaves in August were sampled from 2 to 4 different plants in each plot in order to be chemically analyzed. After harvest, leaf greenness was assessed for the fresh sampled leaves by a greenness meter (SPAD 502, Minolta, Osaka, Japan). SPAD readings are closely related to total amount of chlorophyll and nitrogen $(\mathrm{N})$ condition of a leaf (Uddling et al., 2007). Hereafter, leaves were dried at $80^{\circ} \mathrm{C}$ for at least 5 days.

$\mathrm{N}$ concentration was determined by the combustion method with a NC analyzer (NC-900, Sumica, Osaka, Japan).

Sugar content was determined by the phenol-sulfuric acid method (Dubois et al., 1956).

The dried leaf samples were digested to glucose with amyloglucosidase solution (Kabeya and Sakai, 2003) and the starch concentration was determined with Wako Autokit Glucose afterwards (439-90901, Wako Pure Chemical Industries, Ltd., Osaka, Japan). Since leaf starch content is significantly increased in $\mathrm{eCO}_{2}$ treatment (e.g. Koike, 2006), concentrations of the 6 elements are shown on the basis of leaf dry matter subtracting non-structural carbohydrates (starch + sugar) as net values.

Moreover, the prepared dried leaf samples were then digested by nitric acid, hydrogen peroxide method and the concentrations of projected elements ( $\mathrm{P}, \mathrm{K}, \mathrm{Mg}, \mathrm{Mn}$ and $\mathrm{Ca}$ ) of the treated leaf samples were measured with an Inductively Coupled Plasma Mass Spectrometry (ICP-MS; IRIS/IRIS Advantage ICAP, Thermo Fisher Scientific Inc., Massachusetts, U.S.A.) analysis.

\subsection{Statistical analysis}

The defined threshold level of significance for rejection of the null hypothesis was set at $\alpha=0.05$. The values of each species and for each treatment were averaged in order to provide the sample estimate for the actual replicate. The data of each parameter were standardized to have a mean equal to 0 and a standard deviation equal to 1 ; this procedure allows a fair inter-comparison and minimizes the heterogeneity (Saitanis et al., 2014; 2015). All the standardized data were subjected to split-plot general linear model 
Table 1. Summary of the GLM results for the value of concentration of starch and sugar, P, N, K, Mg, Mn, Ca and SPAD readings in leaves of 2 oaks. The values represent the $\mathrm{F}$ values and the number in the parentheses the $p$-values. Bold text shows significance of the factors. Leaf is consisted of the three types of leaves: a) first-flushed leaves sampled in late May (leaf age was c.a. 40 days old), b) first-flushed sampled in August, and c) second-flushed sampled in August. Gas treatment includes the ambient air, elevated $\mathrm{O}_{3}$, elevated $\mathrm{CO}_{2}$, elevated $\mathrm{O}_{3}$ and $\mathrm{CO}_{2}$. The two species subjected to the treatments were $Q$. mongolica and Q. serrata. Three replications were used for each treatment. Analysis was conducted using standardized data.

\begin{tabular}{|c|c|c|c|c|c|c|c|}
\hline & Leaf & Gas & Species & Leaf $\times$ Gas & Leaf $\times$ Species & Gas $\times$ Species & $\begin{array}{c}\text { Leaf } \times \text { Gas } \times \\
\text { Species }\end{array}$ \\
\hline Starch & $87.59(<0.001)$ & $39.45(<0.001)$ & $1.74(=0.193)$ & $3.25(<0.010)$ & $1.59(=0.215)$ & $3.36(<0.050)$ & $1.15(=0.351)$ \\
\hline Sugar & $9.39(<0.001)$ & $0.13(=0.940)$ & $2.89(=0.095)$ & $0.61(=0.721)$ & $0.49(=0.124)$ & $0.69(=0.560)$ & $0.30(=0.932)$ \\
\hline $\mathbf{P}$ & $13.95(<0.001)$ & $1.79(=0.161)$ & $3.89(=0.054)$ & $0.59(=0.734)$ & $0.91(=0.408)$ & $0.50(=0.687)$ & $0.62(=0.715)$ \\
\hline $\mathbf{N}$ & $6.63(<0.010)$ & $12.91(<0.001)$ & $5.24(<0.050)$ & $0.62(=0.716)$ & $7.16(<0.010)$ & $1.28(=0.293)$ & $0.65(=0.693)$ \\
\hline K & $9.55(<0.001)$ & $3.30(<0.050)$ & $3.18(=0.081)$ & $0.68(=0.664)$ & $3.13(=0.053)$ & $3.36(<0.050)$ & $0.54(=0.773)$ \\
\hline Mg & $37.66(<0.001)$ & $5.17(<0.010)$ & $136.11(<0.001)$ & $1.20(=0.319)$ & $16.66(<0.001)$ & $2.20(=0.101)$ & $1.20(=0.322)$ \\
\hline Mn & $27.87(<0.001)$ & $6.35(<0.010)$ & $72.05(<0.001)$ & $1.45(=0.216)$ & $8.22(<0.001)$ & $3.35(<0.050)$ & $1.23(=0.306)$ \\
\hline $\mathrm{Ca}$ & $67.25(<0.001)$ & $4.97(<0.010)$ & $0.88(=0.354)$ & $2.57(=0.051)$ & $3.14(=0.055)$ & $0.95(=0.424)$ & $0.39(=0.881)$ \\
\hline SPAD & $20.56(<0.001)$ & $1.85(=0.151)$ & $18.93(<0.001)$ & $0.62(=0.714)$ & $9.10(<0.001)$ & $1.94(=0.136)$ & $0.69(=0.657)$ \\
\hline
\end{tabular}

(GLM) randomized by blocks (Crawley, 2005), and if there were significant effects, Tukey range, post-hoc test was followed.

To the purpose of the presentation of the data, we present the net values (as shown in above); the results of the GLM are shown in Table 1. Since the responses to the gas treatments were not depended on the leaf types (except starch contents) or the combination of "leaf type" and "species", the data are represented only for the interactions: Gas $\times$ Species and Leaf $\times$ Species (Tables 2 and 3 , respectively); the differences were marked based on the Tukey range, post-hoc tests. The Cohen's d (Cohen, 1977) was calculated for the concentrations of starch, sugar, $\mathrm{P}, \mathrm{N}, \mathrm{K}, \mathrm{Mg}$, $\mathrm{Mn}$ and $\mathrm{Ca}$, independently from leaf types and species.

A principal component analysis (PCA) with varimax rotation (Kaiser, 1958), based on the Cohen's d, was conducted using the pooled data of the 2 species. The gas treatments were used as the classification criteria in assessing the relationships among them and the nutrients. PCA was conducted in order to reduce the dimensionality of the data matrix, avoid redundancy, and highlight relationships (Abdi and Williams, 2010). The continuity of the variables and the number of elements observed were bigger than the number of the original variables. Data were processed and analyzed using MS EXCEL 2010 and STATISTICA v.10 software.

\section{Results}

Table 1 indicates that the 3 leaf types ("Leaf") (first-flushed in May and first- and second-flushed in August) had significantly affected carbohydrates and nutrient element contents and SPAD. Leaf starch and $\mathrm{N}, \mathrm{K}, \mathrm{Mg}, \mathrm{Mn}$ and $\mathrm{Ca}$ contents were significantly affected by the gas treatments ("Gas") which included ambient air, $\mathrm{eO}_{3}, \mathrm{eCO}_{2}$, and e $\left(\mathrm{O}_{3}+\mathrm{CO}_{2}\right)$. Moreover, species ("Species") as well as interaction of Leaf $\times$ Species were found to have significant effects on leaf N, Mg, Mn and SPAD. Meanwhile, the inter- actions of Gas $\times$ Species, starch and leaf $\mathrm{K}$, Mn were found to be significant. As for the species difference in non-structural carbohydrates and these elements, Table 1 shows that $\mathrm{N}, \mathrm{Mg}$ and $\mathrm{Mn}$ were significantly different between species. No significant effect was observed on either Leaf $\times$ Gas or Leaf $\times$ Gas $\times$ Species interactions for mineral nutrients; only starch was observed to be significantly affected by the interaction of Leaf $\times$ Gas.

Starch concentrations were significantly decreased by $\mathrm{eO}_{3}$ treatments as compared with control (Table 2). Meanwhile, starch was significantly increased by both $\mathrm{eCO}_{2}$ and e $\left(\mathrm{O}_{3}+\mathrm{CO}_{2}\right)$. For $Q m$, although there was no significant difference on starch at $\mathrm{eO}_{3}$, we observed that starch was $14 \%$ lower at $\mathrm{eO}_{3}$ but significantly recovered by $78 \%$ from $\mathrm{eO}_{3}$ to $\mathrm{e}\left(\mathrm{O}_{3}+\mathrm{CO}_{2}\right)$. This recovery was smaller than that of $Q s$ (which is $110 \%$ ). Apparently, with $\mathrm{eCO}_{2}$ and $\mathrm{e}\left(\mathrm{O}_{3}+\mathrm{CO}_{2}\right)$ treatments in both oaks, $\mathrm{N}$ concentration was significantly decreased while starch content was significantly increased. Sugar concentrations were significantly decreased in the $2^{\text {nd }}$ flush of both oaks in August (Table 3). Starch and P concentrations were significantly decreased; however leaf $\mathrm{N}$ and $\mathrm{K}$ concentrations were significantly increased in August at the $1^{\text {st }}$ or $2^{\text {nd }}$ flush for both oaks.

Foliar $\mathrm{Mg}, \mathrm{Mn}$ and $\mathrm{Ca}$ were significantly decreased by $\mathrm{eO}_{3}$ treatments (Table 2). The decrease in $\mathrm{Mg}$ was clearly found in $Q s$. We found that $\mathrm{Mg}$ concentration in both types of leaves of $Q s$ was higher than that of $Q m$ (Table 3). For 2 oaks, the $1^{\text {st }}$ flush leaves had higher $\mathrm{Mg}$ concentration compared with the $2^{\text {nd }}$ flush leaves. For $Q m, \mathrm{Mg}$ was decreased from May to August at the $1^{\text {st }}$ flush, and also it was significantly lower at the $2^{\text {nd }}$ flush. For $Q s, \mathrm{Mg}$ was not changed from May to the $1^{\text {st }}$ flush in August, but was significantly lower at the $2^{\text {nd }}$ flush.

In the contrast, for both $Q m$ and $Q s$, Mn concentration was significantly increased at the $1^{\text {st }}$ flush in August and had significantly higher value than at the $2^{\text {nd }}$ flush. As for foliar Ca concentration 
Table 2. Mean net values $\left( \pm \mathrm{SD}\right.$ ) of the concentrations ( $\mathrm{mg} \mathrm{g}^{-1}$ dry mass) of starch and sugar, $\mathrm{P}, \mathrm{N}, \mathrm{K}, \mathrm{Mg}$, $\mathrm{Mn}, \mathrm{Ca}$ and the readings of SPAD (arbitrary units) under the 4 gas treatments (Gas $\times$ Species). The values are shown separately for the species $Q$. mongolica $(Q m)$ and $Q$. serrata $(Q s)$ and pooled for both species (pooled = main effects of the treatment) . Comparisons were made within each line of the table (i.e. each variable). The lowercase letters above the mean values indicate the significant differences among the 4 gas treatments of the pooled data while the uppercase indicate the differences among the 4 gas treatments for the $Q m$ and $Q s$. The results of each variable obtained by one GLM analysis or a Tukey range, post-hoc test, after significant results of the GLM analysis, based on standardized data. Means within each variable marked with different letter differ statistically significantly at a level of significance $\alpha=0.05$.

\begin{tabular}{|c|c|c|c|c|c|c|}
\hline & \multicolumn{3}{|c|}{ Ambient } & \multicolumn{3}{|c|}{ Elevated $\mathrm{O}_{3}$} \\
\hline & $Q m$ & Qs & Pooled & $Q m$ & Qs & Pooled \\
\hline Starch & $42.87^{\mathrm{A}}(26.10)$ & $56.93^{\mathrm{AB}}(17.90)$ & $49.90^{\mathrm{a}}(22.89)$ & $36.64^{\mathrm{A}}(21.48)$ & $37.62^{\mathrm{A}}(20.91)$ & $37.13^{\mathrm{b}}(20.57)$ \\
\hline Sugar & $69.39^{\mathrm{A}}(9.42)$ & $66.94^{\mathrm{A}}(6.75)$ & $68.17^{\mathrm{a}}(8.05)$ & $68.29^{\mathrm{A}}(12.97)$ & $68.98^{\mathrm{A}}(9.11)$ & $68.64^{\mathrm{a}}(10.88)$ \\
\hline $\mathbf{P}$ & $1.17^{\mathrm{A}}(0.53)$ & $1.07^{\mathrm{A}}(0.47)$ & $1.12^{\mathrm{a}}(0.49)$ & $1.41^{\mathrm{A}}(0.43)$ & $1.22^{\mathrm{A}}(0.38)$ & $1.32^{\mathrm{a}}(0.41)$ \\
\hline $\mathbf{N}$ & $2.01^{\mathrm{A}}(0.28)$ & $1.77^{\mathrm{ABC}}(0.19)$ & $1.89^{\mathrm{a}}(0.26)$ & $1.87^{\mathrm{AB}}(0.20)$ & $1.80^{\mathrm{ABC}}(0.21)$ & $1.84^{\mathrm{a}}(0.20)$ \\
\hline $\mathbf{K}$ & $7.59^{\mathrm{AB}}(1.22)$ & $7.20^{\mathrm{AB}}(1.19)$ & $7.39^{\mathrm{ab}}(1.19)$ & $8.05^{\mathrm{AB}}(1.46)$ & $7.87^{\mathrm{AB}}(1.24)$ & $7.96^{\mathrm{b}}(1.32)$ \\
\hline Mg & $2.44^{\mathrm{AC}}(0.31)$ & $4.03^{\mathrm{B}}(1.36)$ & $3.24^{\mathrm{a}}(1.26)$ & $2.03^{\mathrm{A}}(0.53)$ & $3.12^{\mathrm{CD}}(1.03)$ & $2.57^{\mathrm{b}}(0.97)$ \\
\hline Mn & $0.32^{\mathrm{A}}(0.13)$ & $0.17^{\mathrm{CD}}(0.04)$ & $0.25^{\mathrm{a}}(0.12)$ & $0.23^{\mathrm{BC}}(0.08)$ & $0.14^{\mathrm{D}}(0.02)$ & $0.18^{\mathrm{b}}(0.07)$ \\
\hline $\mathbf{C a}$ & $21.33^{\mathrm{A}}(7.82)$ & $18.67^{\mathrm{AB}}(4.82)$ & $20.00^{\mathrm{a}}(6.45)$ & $16.11^{\mathrm{AB}}(4.20)$ & $14.99^{\mathrm{B}}(2.79)$ & $15.55^{\mathrm{b}}(3.50)$ \\
\hline \multirow[t]{3}{*}{ SPAD } & $34.16^{\mathrm{AB}}(4.27)$ & $34.90^{\mathrm{A}}(2.75)$ & $34.53^{\mathrm{a}}(3.51)$ & $29.72^{\mathrm{B}}(4.80)$ & $34.89^{\mathrm{A}}(4.38)$ & $32.31^{\mathrm{a}}(5.19)$ \\
\hline & \multicolumn{4}{|c|}{ Elevated $\mathrm{CO}_{2}$} & \multicolumn{2}{|c|}{ Elevated $\left(\mathrm{O}_{3}+\mathrm{CO}_{2}\right)$} \\
\hline & $Q m$ & $Q s$ & Pooled & $Q m$ & $Q s$ & Pooled \\
\hline Starch & $88.88^{\mathrm{D}}(37.21)$ & $77.45^{\mathrm{BCD}}(37.23)$ & $83.17^{\mathrm{c}}(36.59)$ & $65.37^{\mathrm{BC}}(35.16)$ & $79.34^{\mathrm{CD}}(19.97)$ & $72.36^{\mathrm{c}}(28.65)$ \\
\hline Sugar & $72.39^{\mathrm{A}}(5.97)$ & $65.66^{\mathrm{A}}(6.65)$ & $69.03^{\mathrm{a}}(7.04)$ & $69.57^{\mathrm{A}}(8.10)$ & $65.30^{\mathrm{A}}(7.04)$ & $67.44^{\mathrm{a}}(7.68)$ \\
\hline $\mathbf{P}$ & $1.30^{\mathrm{A}}(0.42)$ & $1.20^{\mathrm{A}}(0.54)$ & $1.25^{\mathrm{a}}(0.47)$ & $1.21^{\mathrm{A}}(0.68)$ & $0.81^{\mathrm{A}}(0.43)$ & $1.01^{\mathrm{a}}(0.59)$ \\
\hline $\mathbf{N}$ & $1.61^{\mathrm{BC}}(0.23)$ & $1.60^{\mathrm{C}}(0.19)$ & $1.60^{\mathrm{b}}(0.21)$ & $1.64^{\mathrm{BC}}(0.17)$ & $1.57^{\mathrm{C}}(0.15)$ & $1.60^{\mathrm{b}}(0.16)$ \\
\hline $\mathbf{K}$ & $6.63^{\mathrm{B}}(0.96)$ & $7.12^{\mathrm{AB}}(1.13)$ & $6.88^{\mathrm{a}}(1.05)$ & $8.51^{\mathrm{A}}(1.06)$ & $6.79^{\mathrm{B}}(1.28)$ & $7.65^{\mathrm{ab}}(1.44)$ \\
\hline Mg & $2.11^{\mathrm{A}}(0.33)$ & $3.56^{\mathrm{BD}}(1.21)$ & $2.83^{\mathrm{ab}}(1.14)$ & $2.11^{\mathrm{A}}(0.55)$ & $4.14^{\mathrm{B}}(1.23)$ & $3.13^{\mathrm{a}}(1.39)$ \\
\hline Mn & $0.26^{\mathrm{AB}}(0.07)$ & $0.21^{\mathrm{BCD}}(0.06)$ & $0.23^{\mathrm{a}}(0.07)$ & $0.25^{\mathrm{B}}(0.07)$ & $0.16^{\mathrm{CD}}(0.04)$ & $0.21^{\mathrm{ab}}(0.07)$ \\
\hline $\mathrm{Ca}$ & $19.55^{\mathrm{AB}}(9.21)$ & $18.63^{\mathrm{AB}}(6.18)$ & $19.09^{\mathrm{a}}(7.62)$ & $18.03^{\mathrm{AB}}(8.03)$ & $19.47^{\mathrm{AB}}(7.38)$ & $18.75^{\mathrm{ab}}(7.52)$ \\
\hline SPAD & $32.06^{\mathrm{AB}}(5.24)$ & $34.32^{\mathrm{A}}(2.43)$ & $33.19^{\mathrm{a}}(4.13)$ & $30.54^{\mathrm{AB}}(5.04)$ & $34.81^{\mathrm{A}}(2.40)$ & $32.68^{\mathrm{a}}(4.41)$ \\
\hline
\end{tabular}

Note: Since foliar starch contents were significantly increased in elevated- $\mathrm{CO}_{2}$-grown seedlings, the concentrations of $\mathrm{P}$, $\mathrm{N}$, $\mathrm{K}$, $\mathrm{Mg}, \mathrm{Mn}$, and $\mathrm{Ca}$ are shown on the basis of leaf dry matter subtracting non-structural carbohydrates (starch + sugar).

for both oaks, it was significantly increased at the $1^{\text {st }}$ flush but was significantly lower at the $2^{\text {nd }}$ flush in August. No difference in Ca was found between species.

SPAD values did not significantly differ among the 4 treatments (Table 2), whereas SPAD values of $Q s$ were significantly higher than those of $Q m$ at $\mathrm{eO}_{3}$. Given that they were not different at ambient air, it can be stated that $\mathrm{eO}_{3}$ had higher effect on leaf greenness of $Q m$ than that of $Q s$. Based on Table 3, SPAD values were significantly increased at both the $1^{\text {st }}$ and $2^{\text {nd }}$ flush in August. At the $1^{\text {st }}$ flush in August, SPAD value of $Q s$ was significantly increased while at the $2^{\text {nd }}$ flush, $Q m$ 's was significantly higher.

Principal component analysis (PCA) was conducted in order to identify elements associated with gas treatments and screen the studied variables as indices in assessing the gas treatment effects on the 2 oaks (Fig. 1). PC1 and PC2 explained $100 \%$ of variance and $\mathrm{PC} 1$ can be considered as the major axis, with $54 \%$ explanation of the total variance. Factor loading is a coefficient which is related to the correlation with the principal components. Loadings range from -1 to 1 , and values close to -1 or 1 indicate that the factor strongly affects the variable. Values close to 0 indicate weak effect of the factor on the variable. High loading reflect the high correlation of the relevant variables with the principal component.

Highest loading on PC1 had the variables starch, N, Mn and Ca (whose factor loading are $0.980,0.977,0.962$ and 0.907 , respectively), explaining $22.3,22.2,21.5$ and $19.1 \%$, respectively, of the variance of this factor. On the other hand, high loading on $\mathrm{PC} 2$ had the variables sugar, $\mathrm{P}, \mathrm{K}$ and $\mathrm{Mg}$ (whose factor loading are $0.993,0.989,0.902$ and 0.761 , respectively), explaining 26.7, $26.5,22.0$ and $15.7 \%$, respectively. Thus, the other highly intercorrelated group of variables is that of sugar, $\mathrm{P}, \mathrm{K}$ and $\mathrm{Mg}$. $\mathrm{eO}_{3}$ and $\left(\mathrm{O}_{3}+\mathrm{CO}_{2}\right)$ contributes 58.9 and $39.1 \%$ to $\mathrm{PC} 1$, respectively, while $\mathrm{eCO}_{2}$ and $\mathrm{e}\left(\mathrm{O}_{3}+\mathrm{CO}_{2}\right)$ contribute 64.7 and $27.6 \%$, respectively, to $\mathrm{PC} 2$.

\section{Discussion}

As Gs is usually reduced by eCO${ }_{2}$ (e.g. Norby and Zak, 2011), plants have higher water use efficiency and lower $\mathrm{O}_{3}$ uptake (e.g. Koike et al., 2012), which may change the absorption of watersoluble elements with aging of leaves (Hoshika et al., 2013). 
Table 3. Mean net values $( \pm \mathrm{SD})$ of the concentrations ( $\mathrm{mg} \mathrm{g}^{-1}$ dry mass) of starch and sugar, $\mathrm{P}, \mathrm{N}, \mathrm{K}, \mathrm{Mg}$, $\mathrm{Mn}, \mathrm{Ca}$ and the readings of SPAD (arbitrary units) in the 3 types of leaves, independently of the gas treatment (Leaf $\times$ Species). The values are shown separately for the species $Q$. mongolica $(Q m)$ and $Q$. serrata $(Q s)$ and pooled for both species (pooled = main effects of the leaf type). Comparisons were made within each line of the table (i.e. each variable). The lowercase letters above the mean values indicate the significant differences among the 3 types of leaves of the pooled data while the uppercase indicate the differences among the 3 types of leaves for the $Q m$ and $Q s$. The results of each variable obtained by one GLM analysis or a Tukey range, Post-hoc test, after significant results of the GLM analysis, based on standardized data. Means within each variable marked with different letter differ statistically significantly at a level of significance $\alpha=0.05$.

\begin{tabular}{|c|c|c|c|c|c|c|c|c|c|}
\hline & \multicolumn{3}{|c|}{$1^{\text {st }}$ flush leaves - May } & \multicolumn{3}{|c|}{$1^{\text {st }}$ flush leaves - August } & \multicolumn{3}{|c|}{$2^{\text {nd }}$ flush leaves - August } \\
\hline & $Q m$ & $Q s$ & Pooled & $Q m$ & $Q s$ & Pooled & $Q m$ & $Q s$ & Pooled \\
\hline \multirow[t]{2}{*}{ Starch } & $93.60^{\mathrm{A}}$ & $89.61^{\mathrm{A}}$ & $91.60^{\mathrm{a}}$ & $37.56^{\mathrm{B}}$ & $46.57^{\mathrm{B}}$ & $42.07^{b}$ & $44.17^{\mathrm{B}}$ & $52.33^{\mathrm{B}}$ & $48.25^{\mathrm{b}}$ \\
\hline & $(27.43)$ & $(27.57)$ & (26.97) & (19.19) & $(23.33)$ & $(21.40)$ & $(30.91)$ & $(17.33)$ & $(24.86)$ \\
\hline \multirow[t]{2}{*}{ Sugar } & $73.94^{\mathrm{A}}$ & $71.45^{\mathrm{A}}$ & $72.70^{\mathrm{a}}$ & $72.22^{\mathrm{A}}$ & $66.48^{\mathrm{A}}$ & $69.35^{\mathrm{a}}$ & $63.57^{\mathrm{A}}$ & $62.23^{\mathrm{A}}$ & $62.90^{\mathrm{b}}$ \\
\hline & (6.09) & $(3.55)$ & $(5.04)$ & $(7.79)$ & $(8.71)$ & $(8.60)$ & $(10.15)$ & $(5.78)$ & $(8.11)$ \\
\hline \multirow[t]{2}{*}{$\mathbf{P}$} & $1.60^{\mathrm{A}}$ & $1.42^{\mathrm{A}}$ & $1.51^{\mathrm{a}}$ & $1.34^{\mathrm{A}}$ & $0.96^{\mathrm{A}}$ & $1.15^{\mathrm{b}}$ & $0.88^{\mathrm{A}}$ & $0.84^{\mathrm{A}}$ & $0.86^{\mathrm{b}}$ \\
\hline & $(0.15)$ & $(0.12)$ & $(0.17)$ & $(0.64)$ & $(0.55)$ & $(0.61)$ & $(0.33)$ & $(0.42)$ & $(0.37)$ \\
\hline \multirow[t]{2}{*}{$\mathbf{N}$} & $1.64^{\mathrm{A}}$ & $1.76^{\mathrm{AB}}$ & $1.70^{\mathrm{a}}$ & $1.73^{\mathrm{A}}$ & $1.58^{\mathrm{A}}$ & $1.66^{\mathrm{a}}$ & $1.97^{\mathrm{B}}$ & $1.71^{\mathrm{A}}$ & $1.84^{\mathrm{b}}$ \\
\hline & $(0.19)$ & $(0.18)$ & $(0.19)$ & $(0.25)$ & $(0.19)$ & $(0.23)$ & $(0.28)$ & $(0.22)$ & $(0.28)$ \\
\hline \multirow[t]{2}{*}{$\mathbf{K}$} & $7.12^{\mathrm{AB}}$ & $6.30^{\mathrm{B}}$ & $6.71^{\mathrm{a}}$ & $8.18^{\mathrm{A}}$ & $7.21^{\mathrm{AB}}$ & $7.69^{b}$ & $7.79^{\mathrm{A}}$ & $8.22^{\mathrm{A}}$ & $8.01^{\mathrm{b}}$ \\
\hline & (0.98) & $(0.57)$ & $(0.89)$ & $(1.52)$ & (1.18) & $(1.42)$ & $(1.35)$ & (1.01) & (1.19) \\
\hline \multirow[t]{2}{*}{ Mg } & $2.61^{A}$ & $4.36^{\mathrm{B}}$ & $3.48^{\mathrm{a}}$ & $2.03^{\mathrm{AC}}$ & $4.36^{\mathrm{B}}$ & $3.19^{\mathrm{a}}$ & $1.89^{\mathrm{C}}$ & $2.41^{\mathrm{AC}}$ & $2.15^{b}$ \\
\hline & $(0.21)$ & $(0.43)$ & $(0.96)$ & $(0.44)$ & $(1.25)$ & $(1.50)$ & $(0.32)$ & $(0.57)$ & $(0.52)$ \\
\hline \multirow[t]{2}{*}{ Mn } & $0.22^{\mathrm{A}}$ & $0.14^{\mathrm{B}}$ & $0.18^{\mathrm{a}}$ & $0.36^{\mathrm{C}}$ & $0.20^{\mathrm{AB}}$ & $0.28^{\mathrm{b}}$ & $0.22^{\mathrm{A}}$ & $0.16^{\mathrm{AB}}$ & $0.19^{\mathrm{a}}$ \\
\hline & $(0.03)$ & $(0.02)$ & $(0.05)$ & $(0.10)$ & $(0.05)$ & $(0.11)$ & $(0.07)$ & $(0.05)$ & $(0.06)$ \\
\hline \multirow[t]{2}{*}{ Ca } & $11.59^{\mathrm{A}}$ & $13.18^{\mathrm{A}}$ & $12.38^{\mathrm{a}}$ & $26.56^{\mathrm{C}}$ & $22.88^{\mathrm{C}}$ & $24.72^{c}$ & $18.11^{\mathrm{B}}$ & $17.76^{\mathrm{B}}$ & $17.94^{\mathrm{b}}$ \\
\hline & $(2.55)$ & $(1.91)$ & $(2.35)$ & $(5.84)$ & $(5.64)$ & $(5.93)$ & $(3.79)$ & $(3.59)$ & $(3.62)$ \\
\hline \multirow[t]{2}{*}{ SPAD } & $27.75^{\mathrm{A}}$ & $32.47^{\mathrm{BC}}$ & $30.11^{\mathrm{a}}$ & $30.89^{\mathrm{AB}}$ & $36.68^{\mathrm{D}}$ & $33.78^{\mathrm{b}}$ & $36.21^{\mathrm{D}}$ & $35.05^{\mathrm{CD}}$ & $35.63^{b}$ \\
\hline & $(2.12)$ & $(1.24)$ & $(2.95)$ & $(5.26)$ & $(3.68)$ & $(5.33)$ & $(2.42)$ & (1.79) & $(2.17)$ \\
\hline
\end{tabular}

Note: Since foliar starch contents were significantly increased in elevated- $\mathrm{CO}_{2}$-grown seedlings, the concentrations of $\mathrm{P}, \mathrm{N}, \mathrm{K}, \mathrm{Mg}, \mathrm{Mn}$, and $\mathrm{Ca}$ are shown on the basis of leaf dry matter subtracting non-structural carbohydrates (starch + sugar).

According to Yamaguchi et al. (2011) and Kitao et al. (2015), Gs was relatively higher in $Q m$ than in $Q s$. The decrease of $\mathrm{Mg}$, $\mathrm{Mn}$ and $\mathrm{Ca}$ in $\mathrm{eO}_{3}$, in both species, maybe because of declined photosynthetic function and low Gs which were induced by $\mathrm{eO}_{3}$ (Yamaguchi et al., 2011; Kitao et al., 2015), as was also found in Siebolds' beech sapling during young stage of leaf until late-July (Hoshika et al., 2012; 2013).

Carbohydrates (e.g. starch and sugar) are produced by green plants served as storage products of energy (e.g. Keutgen and Chen, 2001; Koike, 2006). An increase of starch at $\mathrm{eCO}_{2}$ has also been observed in our study in coincidence with many researches' results (e.g. Norby and Zak, 2011). This may be attributed to a feedback mechanism which reduces the sucrose synthesis in the cytosol; as a result, triose phosphate is exported from the chloroplast, finally stimulating starch accumulation in the chloroplast (Sharkey, 1985; Katny et al., 2005). Net photosynthetic rate was decreased by $\mathrm{eO}_{3}$ but this reduction was slightly recovered by $\mathrm{e}\left(\mathrm{O}_{3}+\mathrm{CO}_{2}\right)$ at the $1^{\text {st }}$ flush and by $\mathrm{eCO}_{2}$ at the $2^{\text {nd }}$ flush for $Q m$; while it was increased by e $\left(\mathrm{O}_{3}+\mathrm{CO}_{2}\right)$ for $Q s$ during the entire flush time (Kitao et al., 2015). These trends have suggested that Qs may have higher ability for the recover from $\mathrm{O}_{3}$ damages and may be more tolerant to $\mathrm{eO}_{3}$ than $\mathrm{Qm}$ under $\mathrm{eCO}_{2}$ based on the summary made by Kohno et al. (2005) and Yamaguchi et al. (2011).

No significant effects were observed in foliar P concentration at $\mathrm{eO}_{3}$ for both species at the present study, which was in agreement with the results of Wang et al. (2015). Although we hypothesized that leaf $\mathrm{P}$ would be increased under $\mathrm{eCO}_{2}$ since the acquisition of $\mathrm{P}$ is strongly affected by physiological condition of host plants through the morphological and the physiological properties of rhizosphere (Adalsteinsson et al., 1994; Ruiz et al., 1996; Kayama et al., 2005; Kayama and Yamanaka, 2014; Wang et al., 2015), there was no difference in leaf $\mathrm{P}$ at $\mathrm{eCO}_{2}$. This was also supported by Conroy (1992), indicating the view that $\mathrm{eCO}_{2}$ increased the $\mathrm{P}$ demand of leaves. As one of the most actively sources for carbohydrates, leaves may prefer the photosynthetic carbon reduction cycle at $\mathrm{eCO}_{2}$ (Fangmeier et al., 1997).

On the other hand, P concentration was significantly decreased in August for both oaks at the $1^{\text {st }}$ flush leaves and the values continued to be significantly decreased at the $2^{\text {nd }}$ flush of leaves most likely due to $\mathrm{P}$ consumption by the leaf flushing. This change is also supported by general trend: $\mathrm{P}$ is an essential component of cellular membranes and nucleic acid and is recognized as a significant element for energy storage and transfer (Raghothama, 1999; 


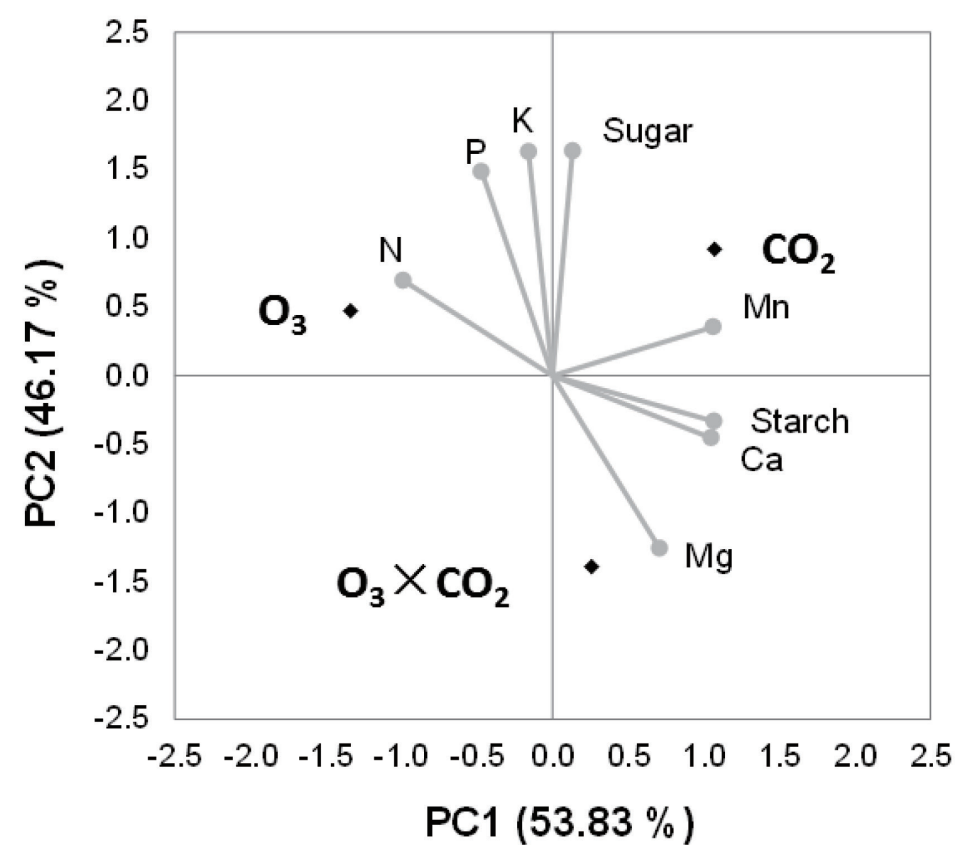

Fig. 1. Biplot of the PCA ordination (with varimax rotation) of the 3 gas treatments, based on their Cohen's d of the gas-induced changes on the concentrations of starch and sugar, $\mathrm{P}, \mathrm{N}, \mathrm{K}, \mathrm{Mg}, \mathrm{Mn}, \mathrm{Ca}$. The circular dot points represent the scores of each response variable, while rhombus dot points represent the scores of the gas treatments, all after Cohen's $\mathrm{d}$.

Singh et al., 2013).

As one of the most important macro-nutrients, $\mathrm{N}$ is the major component of protein and various enzymes, which importantly affects not only energy reserves but also the process of photosynthesis (Marschner, 2012). $\mathrm{eO}_{3}$ did not significantly affect leaf $\mathrm{N}$ for both $Q m$ and $Q s$. This result is consistent with previous results from former researches with other tree species like holm oak (e.g. Baldantoni et al., 2011; Matyssek and Sandermann, 2003). Foliar $\mathrm{N}$ concentration is decreased due to the reduced demand for $\mathrm{N}$ in $\mathrm{eCO}_{2}$ (e.g. Rogers et al., 1993). At $\mathrm{eCO}_{2}$ and $\mathrm{e}\left(\mathrm{O}_{3}+\mathrm{CO}_{2}\right)$ treatments, oaks did not require to accumulate much $\mathrm{N}$ because of enriched $\mathrm{CO}_{2}$ environment (Norby and Zak, 2011). This result was supported by some other researches; such as a potato variety (Fangmeier et al., 2002) and larch species (Koike et al., 2012). The reduced $\mathrm{N}$ concentration under $\mathrm{eCO}_{2}$ may be also attributed to the limitation in nutrients supplies from soil. In addition, the markedly increased leaf $\mathrm{N}$ of $\mathrm{Qm}$ at the $2^{\text {nd }}$ flush in August could be due to the physiological or morphological enhancement of roots (Eguchi et al., 2008) driven by relatively higher net photosynthetic rate (Kitao et al., 2015), which promote $\mathrm{N}$ absorption.

Although $\mathrm{K}$ is not a direct component of a plant body, it regulates the translocation of photosynthates in sap of plants. High level of $\mathrm{K}$ may accelerate the various functions in photosynthesis, such as net carbon exchange, phloem loading, metabolic conversion of sucrose, etc. (Conti and Geiger, 1982). Despite the fact that some previous researches indicated $\mathrm{eO}_{3}$ and $\mathrm{eCO}_{2}$ treatment decreased foliar $\mathrm{K}$ in potato and beech (e.g. Fangmeier et al., 2002; Thomas et al., 2006), what we found in this study (Table 2) is in consistence with Wang et al. (2015) where leaf $\mathrm{K}$ was not clearly different at $\mathrm{eO}_{3}$ and $\mathrm{eCO}_{2}$ from that grown under ambient. It was possibly because the decreased photosynthetic rate
(Kitao et al., 2015) was somehow offset by the enhanced phytohormones induced by $\mathrm{eO}_{3}$ or $\mathrm{eCO}_{2}$ (Yong et al., 2000; Winwood et al., 2007; Matyssek et al., 2012), thereby regulating the foliar $\mathrm{K}$ independent with the specific gas treatments. Moreover, the high leaf $\mathrm{K}$ in August, both the $1^{\text {st }}$ and $2^{\text {nd }}$ flush, was likely connected with remobilisable stored water or with succulence so that $\mathrm{K}$ may be accumulated in vacuoles (Von Willert et al., 1992; Cornelissen et al., 1997).

$\mathrm{P}, \mathrm{K}$ and $\mathrm{Mg}$ are known to be water soluble mobile in the phloem and easily re-translocated from older to younger leaves (Marschner, 2012). Mg is the central atom of chlorophyll pigment and essential for the ribosomes aggregation. Therefore, $\mathrm{Mg}$ is usually considered as an indicator of leaf greenness and many physiological functions (Shaul, 2002; Teklic et al., 2009). In the present study, the lower result of leaf $\mathrm{Mg}$ at $\mathrm{eO}_{3}$ may also be associated with $\mathrm{eO}_{3}$ accelerated leaf senescence (e.g. Fuhrer et al., 1990; Fangmeier et al., 2002) and reduction of water use efficiency induced by stomatal sluggishness at $\mathrm{eO}_{3}$ (Hoshika et al., 2015). For the $\mathrm{eO}_{3}$ treatment and the $1^{\text {st }}$ flush leaves in both May and August, SPAD readings of $Q s$ were significantly higher than that of $Q m$, which are consistent with the higher leaf $\mathrm{Mg}$ observed in the leaves of $Q s$. Leaf $\mathrm{Mg}$ of $Q s$ was significantly decreased by $\mathrm{eO}_{3}$, which may result from the relatively higher susceptibility of Qs to $\mathrm{eO}_{3}$ (Yamaguchi et al., 2011).

$\mathrm{Ca}$ is a cellular-level second messenger in signal transduction between the environment and plant responses in terms of development and growth (Marschner, 2012). Mn as one of the cofactors together with $\mathrm{Ca}$ and chlorine, promote the water oxidation occurrence in the photosynthetic oxygen evolution (Yachandra et al., 1993; Kitao et al., 1998). Foliar Mn showed the same trend as found in $\mathrm{Ca}$. Leaf mineral content is determined by the balance 
between influx via xylem and phloem, and efflux via phloem (e.g. Larcher, 2003). As $\mathrm{Mn}$ and $\mathrm{Ca}$ are transported from roots to leaves through xylem but poorly mobile in phloem (e.g. Riesen and Feller, 2005; Marschner, 2012), cumulative transpiration flux through stomata would be proportional to leaf Mn concentration (Kitao et al., 2001). In addition, as new flush leaves were developed on the old leaves axles, the nutrient retranslocation of newly flushed leaves were likely great influenced by the nutrient content of old leaves (e.g. Dickson, 1989). Leaf $\mathrm{Mn}$ and $\mathrm{Ca}$ at the $1^{\text {st }}$ flush in August were significantly higher than those in May, which is consistent with the low mobility of $\mathrm{Mn}$ and $\mathrm{Ca}$ (Kitao et al., 2001). Leaf $\mathrm{Mn}$ and $\mathrm{Ca}$ at the $2^{\text {nd }}$ flush, however, had significantly lower values compared with the $1^{\text {st }}$ flush in August. One of the possible reasons is that stomata may become fairly tough until late August as stomata closed (lower Gs) at $\mathrm{eO}_{3}$ by mid-August for the beech seedlings (Hoshika et al., 2012; 2013). Furthermore, the higher leaf $\mathrm{Mn}$ in $\mathrm{Qm}$ might be due to the higher Gs of $\mathrm{Qm}$.

Due to the facts that (a), $\mathrm{N}$ was reduced by $\mathrm{eCO}_{2}$ and e $\mathrm{CO}_{2}+$ $\mathrm{O}_{3}$ ) but it was not affected by $\mathrm{eO}_{3}$, while $\mathrm{Mg}$ was decreased by $\mathrm{eO}_{3}$ but not affected by $\mathrm{eCO}_{2}$ and e $\left(\mathrm{CO}_{2}+\mathrm{O}_{3}\right)$ (Table 2); and (b) one of the highest loading on $\mathrm{PC} 1$ (58.9\% contribution of $\mathrm{eO}_{3}$ ) was that of $\mathrm{N}$ and that $\mathrm{Mg}$ had a high loading on $\mathrm{PC} 2$ $\left(64.7 \%\right.$ contribution of $\left.\mathrm{eCO}_{2}\right), \mathrm{N}$ and $\mathrm{Mg}$ could be a good pair of indexes for assessing the response to the gas treatments on these species. The two elements are also negatively correlated, which means that both of them will simultaneously respond to the gas treatments. Thus, the effect (or no effect) of the dominant pollutant will be observed. If $\mathrm{N}$ is reduced then there is a dominant effect of $\mathrm{CO}_{2}$, whereas if $\mathrm{Mg}$ is decreased then there is a dominant effect of $\mathrm{O}_{3}$. Consequently, investigation of both $\mathrm{N}$ and $\mathrm{Mg}$ would be of help in field studies to discriminate $\mathrm{O}_{3}$ and $\mathrm{CO}_{2}$ effects, especially under the projected high $\mathrm{CO}_{2}$ levels. A positive association was indicated between $\mathrm{eCO}_{2}$ and $\mathrm{e}\left(\mathrm{O}_{3}+\mathrm{CO}_{2}\right)$, which were negatively associated with $\mathrm{eO}_{3}(\mathrm{PC} 1)$.

Eventually, to understand the dynamics of mineral nutrients mobility in the phloem, demands from young developing tissues and nutrient allocation as a whole plant should also be taken into account.

\section{Acknowledgements}

We thank the financial support in part by the Grant-in-aid (JSPS-TypeB 26292075, HokREST and ERTDF-B1105 to T.K.) and Dr. Toshihiro Watanabe of Plant Nutrient Laboratory of Hokkaido University for the guidance of elements analysis with ICP. Thanks are also due to Dr. Masahiro Yamaguchi for invaluable discussion on species difference.

\section{References}

Abdi, H., and Williams, L. J., 2010: Principal component analysis. John Wiley \& Sons, Inc. WIREs Computational Statistics, 2, 433-459.

Adalsteinsson, S., Schjorring, J. K., and Jensén, P., 1994: Regulation of phosphate influx in winter wheat: root-shoot phosphorus interactions. Journal of Plant Physiology, 143, 681-686.

Agathokleous, E., Saitanis, C. J., and Koike, T., 2015: Tropospheric $\mathrm{O}_{3}$, the nightmare of wild plants: a review study. Journal of Agricultural Meteorology, 71, 142-152.
Baldantoni, D., Fagnano, M., and Alfani, A., 2011: Tropospheric ozone effects on chemical composition and decomposition rate of Quercus ilex L. leaves. Science of the Total Environment, 409, 979-984.

Cohen, J., 1977: Statistical Power Analysis for the Behavioral Sciences, Academic Press, New York, pp .474.

Conroy, J. P., 1992: Influence of elevated atmospheric $\mathrm{CO}_{2}$ concentration on plant nutrition. Australian Journal of Botany, 40, $445-456$.

Conti, T. R., and Geiger, D. R., 1982: Potassium nutrition and translocation in sugar beet. Plant Physiology, 70, 168-172.

Cornelissen, J. H. C., Werger, M. J. A., Castro-Díez, P., van Rheenen, J. W. A., and Rowland, A. P., 1997: Foliar nutrients in relation to growth, allocation and leaf traits in seedlings of a wide range of woody plant species and types. Oecologia, 111, 460-469.

Crawley, M. J., 2005: Statistics: An Introduction using R, Wiley, Tokyo, pp. 342.

Dickson, R. E., 1989: Carbon and nitrogen allocation in trees. Annales des Sciences Forestières, 46, 631-647.

Dubois, M., Gilles, K. A., Hamilton, J. K., Rebers, P. A., and Smith, F., 1956: Colorimetric method for determination of sugars and related substances. Analytical Chemistry, 28, 350-356.

Eguchi, N., Karatsu, K., Ueda, T., Funada, R., Takagi, K., Hiura, T., Sasa, K., and Koike, T., 2008: Photosynthetic responses of birch and alder saplings grown in a free air $\mathrm{CO}_{2}$ enrichment system in northern Japan. Trees, 22, 437-447.

Fangmeier, A., De Temmerman, L., Black, C., Persson, K., and Vorne, V., 2002: Effects of elevated $\mathrm{CO}_{2}$ and/or ozone on nutrient concentrations and nutrient uptake of potatoes. European Journal of Agronomy, 17, 353-368.

Fangmeier, A., Grüters, U., Högy, P., Vermehren, B., and Jäger, H. J., 1997: Effect of elevated $\mathrm{CO}_{2}$, nitrogen supply and tropospheric ozone on spring wheat- II. Nutrients (N, P, K, S, Ca, $\mathrm{Mg}, \mathrm{Fe}, \mathrm{Mn}, \mathrm{Zn}$ ). Environmental Pollution, 96, 43-59.

Fares, S., Savi, F., Muller, J., Matteucci, G., and Paoletti, E., 2014: Simultaneous measurements of above and below canopy ozone fluxes help partitioning ozone deposition between its various sinks in a Mediterranean oak forest. Agricultural and Forest Meteorology, 198-199, 181-191.

Fuhrer, J., Lehnherr, B., Moeri, P. B., Tschannen, W., and Shariat-Madari, H., 1990: Effect of ozone on the grain composition of spring wheat grown in open-top field chambers. Environmental Pollution, 65, 181-192.

Hoshika, Y., Katata, G., Deushi, M., Watanabe, M., Koike, T., and Paoletti, E., 2015: Ozone-induced stomatal sluggishness changes carbon and water balance of temperate deciduous forests. Scientific Reports, 5, 09871, doi: 10.1038/srepo9871.

Hoshika, Y., Watanabe, M., Inada, N., and Koike, T., 2012: Ozone-induced stomatal sluggishness develops progressively in Siebold's beech (Fagus crenata). Environmental Pollution, 166, 152-156.

Hoshika, Y., Watanabe, M., Inada, N., Mao, Q. Z., and Koike, T., 2013: Model-based analysis of avoidance of ozone stress by stomatal closure in Siebold's beech (Fagus crenata). Annals of Botany, 112, 1149-1158.

IPCC, 2007: Climate change 2007, mitigation of climate change. Working Group III Contribution to the Fourth Assessment, Report of the intergovernmental Panel on Climate Change.

Izuta, T., 2006: Plants and environmental stresses, Corona publisher, Tokyo, pp. 232. (in Japanese).

Izuta, T., and Nakaji, T., 2003: Effects of high nitrogen load and 
ozone on forest tree species. Eurasian Journal of Forest Research, 6, 155-170.

Kabeya, D., and Sakai, S., 2003: The Role of Roots and Cotyledons as storage organs in early stages of establishment in Quercus crispula: a quantitative analysis of the nonstructural carbohydrate in cotyledons and roots. Annals of Botany, 92, 537-545.

Kaiser, H. F., 1958: Best approximation of a common variance factor space. Working paper, Bureau of Educational Research, University of Illinois, Research Report No. 25.

Karnosky, D. F., Skelly, J. M., Percy, K. E., and Chappelka, A. H., 2007: Perspectives regarding 50 years of research on effects of tropospheric ozone air pollution on US forests. Environmental pollution, 147, 489-506.

Katny, M. A. C., Hoffmann-Thoma, G., Schriera, A. A., Fangmeier, A., Jager, H.-J., and van Bel, A. J. E., 2005: Increase of photosynthesis and starch in potato under elevated $\mathrm{CO}_{2}$ is dependent on leaf age. Journal of Plant Physiology, 162, 429-438.

Kayama, M., Quoreshi, A. M., Uemura, S., and Koike, T., 2005: Differences in growth characteristics and dynamics of elements absorbed in seedlings of three spruce species raised on serpentine soil in northern Japan. Annals of Botany, 95, 661-672.

Kayama, M., and Yamanaka, T., 2014: Growth characteristics of ectomycorrhizal seedlings of Quercus glauca, Quercus salicina and Castanopsis cuspidata planted on acidic soil. Trees, 28, 569-583.

Keutgen, N., and Chen, K., 2001: Responses of citrus leaf photosynthesis, chlorophyll fluorescence, macronutrient and carbohydrate contents to elevated $\mathrm{CO}_{2}$. Journal of Plant Physiology, 158, 1307-1316.

Kikuzawa, K., 1983: Leaf survival of woody plants in deciduous broad-leaved forests. 1. Tall trees. Canadian Journal of Botany, 61, 2133-2139.

Kitao, M., Komatsu, M., Yazaki, K., Kitaoka, S., and Tobita, H., 2015: Growth overcompensation against $\mathrm{O}_{3}$ exposure in two Japanese oak species, Quercus mongolica var. crispula and Quercus serrata, grown under elevated $\mathrm{CO}_{2}$. Environmental Pollution, 206, 133-141.

Kitao, M., Lei, T. T., and Koike, T., 1998: Application of chlorophyll fluorescence to evaluate $\mathrm{Mn}$ tolerance of deciduous broad-leaved tree seedlings native to northern Japan. Tree Physiology, 18, 135-140.

Kitao, M., Lei, T. T., Nakamura, T., and Koike, T., 2001: Manganese toxicity as indicated by visible foliar symptoms of Japanese white birch (Betula platyphylla var. japonica). Environmental Pollution, 111, 89-94.

Kohno, Y., Matsumura, H., Ishii, T., and Izuta, T., 2005: Establishing critical levels of air pollutants for protecting East Asian vegetation-A challenge. In Plant responses to air pollution and global change. (ed. by Omasa, K., Nouchi, I., and De Kok, L. J.) . Springer Verlag, Tokyo, pp. 243-250.

Koike, T., 2006: Global warming and Plants, In Plants under Environmental Stresses. (ed. by Izuta, T.). Corona Publisher, Tokyo, pp. 88-144 (in Japanese).

Koike, T., Mao, Q., Inada, N., Kawaguchi, K., Hoshika, Y., Kita, K., and Watanabe, M., 2012: Growth and photosynthetic response of cuttings of a Hybrid Larch (Larix gmelinii var. japonica $\times$ L. kaempferi) to elevated ozone and/or carbon dioxide. Asian Journal of Atmospheric Environment, 6,104-110.

Koike, T., Watanabe, M., Hoshika, Y., Kitao, M., Matsumura, H., Funada, R., and Izuta, T., 2013: Effects of Ozone on Forest
Ecosystems in East and Southeast Asia. Elsevier Developments in Environmental Science, 13, 371-390.

Larcher, W., 2003: Plant Physiological Ecology, $4^{\text {th }}$ edition, Springer Verlag, Heidelberg, pp. 513.

Marschner, P., 2012: Marschner's Mineral Nutrition of Higher Plants, $3^{\text {rd }}$ edition, Academic Press, London, pp. 135-189.

Maruyama, T., and Miyaura, T., 2007: Recommendation of SATOYAMA study, Showado, Kyoto, pp. 379 (in Japanese).

Matsumura, H., Mikami, C., Sakai, Y., Murayama, K., Izuta, T., Yenekura, T., Miwa, M., and Kohno, Y., 2005: Impacts of elevated $\mathrm{O}_{3}$ and/or $\mathrm{CO}_{2}$ on growth of Betula platyphylla, Betula ermanii, Fagus crenata, Pinus densiflora and Cryptomeria japonica seedlings. Journal of Agricultural Meteorology, 60, 1121-1124.

Matyssek, R., and Sandermann, H., 2003: Impact of Ozone on Trees: An Ecophysiological Perspective. Progress in Botany, 64. Springer-Verlag, Heidelberg, pp. 349-404.

Matyssek, R., Schnyder, H., Oßwald, W., Ernst, D., Munch, J.C., and Pretzsch, H. (ed.), 2012: Growth and defence in plants: resource allocation at multiple scales. Ecological Studies 220, Springer, Heidelberg, pp. 467.

Menitsky, Y. L., 2005: Oaks of Asia (Translated from Russian), Science Publishes, Inc., Enfield, New Hampshire, USA, pp. 549.

Nakashizuka, T., and Iida, S., 1995: Composition, dynamics and disturbance regime of temperate deciduous forests in Monsoon Asia. Vegetatio, 121, 23-30.

NOAA, 2014: Trends in atmospheric carbon dioxide. http://www.esrl.noaa.gov/gmd/ccgg/trends/\#mlo_growth, Accessed on $25^{\text {th }}$ April 2014.

Norby, R. J., and Zak, D. R., 2011: Ecological lessons from FreeAir $\mathrm{CO}_{2}$ Enrichment (FACE) Experiments. Annual Review of Ecology Evolution and Systematics, 42, 181-203.

Oh, K. I., Melville, L. H., and Peterson, R. L., 1995: Comparative structural study of Quercus serrata and Q. acutissima formed by Pisolithus tinctorius and Hebeloma cylindrosporum. Trees, 9, 171-179.

Ohara, T., Akimoto, H., Kurokawa, J., Horii, N., Yamaji, K., Yan, X., and Hayasaka, T., 2007: An Asian emission inventory of anthropogenic emission sources for the period 1980-2020. Atmospheric Chemistry and Physics, 7, 4419-4444.

Paoletti, E., and Grulke, N. E., 2005: Does living in elevated $\mathrm{CO}_{2}$ ameliorate tree response to ozone? A review on stomatal responses. Environmental Pollution, 137, 483-493.

Paoletti, E., Nali, C., and Lorenzini, G., 2002: Photosynthetic behavior of two Italian clones of European beech (Fagus sylvatica Mill.) exposed to ozone. Phyton, 42, 149-155.

Raghothama, K. G., 1999: Phosphate acquisition. Annual Review of Plant Physiology and Plant Molecular Biology, 50, 665-693.

Riesen, O., and Feller, U., 2005: Redistribution of Nickel, Cobalt, Manganese, Zinc, and Cadmium via the phloem in young and maturing wheat. Journal of Plant Nutrition, 28, 421-430.

Rogers, G. S., Payne, L., Milham, P., and Conroy, J., 1993: Nitrogen and phosphorus requirements of cotton and wheat under changing atmospheric $\mathrm{CO}_{2}$ concentrations. In Plant Nutrition from Genetic Engineering to Field Practice. (ed by Barrow, N. J.) . Springer Netherlands, pp. 257-260.

Ruiz, J. M., Belakbir, A., and Romero, L., 1996: Foliar level of phosphorus and its bioindicators in Cucumis melo grafted plants. A possible effect of rootstocks. Journal of Plant Physiology, 149, 400-404.

Saitanis, C., Bari, S. M., Burkey, K. O., Stamatelopoulos, D., and 
Agathokleous, E., 2014: Screening of Bangladeshi winter wheat (Triticum aestivum L.) cultivars for sensitivity to ozone. Environmental Science and Pollution Research, 21, 13560-13571.

Saitanis, C., Lekkas, D. V., Agathokleous, E., and Flouri, F., 2015: Screening agrochemicals as potential protectants of plants against ozone phytotoxicity. Environmental Pollution, 197, 247-255.

Saul, R., 1964: Ozone damage to plants. Annual Review of Phytopathology, 2, 253-266.

Sharkey, T. D., 1985: Photosynthesis in intact leaves of $\mathrm{C}_{3}$ plants: physics, physiology and rate limitations. Botanical Review, 51, 53-105.

Shaul, O., 2002: Magnesium transport and function in plants: the tip of the iceberg. BioMetals, 15, 307-321.

Singh, S. K., Badgujar, G., Reddy, V. R., Fleisher, D. H., and Bunce, J. A., 2013: Carbon dioxide diffusion across stomata and mesophyll and photo-biochemical processes as affected by growth $\mathrm{CO}_{2}$ and phosphorus nutrition in cotton. Journal of Plant Physiology, 170, 801-813.

Sild, E., Pleijel, H., and Sellden, G., 2002: Elevated ozone $\left(\mathrm{O}_{3}\right)$ alters carbohydrate metabolism during grain filling in wheat (Triticum aestivum L.). Agriculture, Ecosystems \& Environment, 92, 71-81.

Solberg, S., Derwent, R. G., Hov, O., Langner, J., and Lindskog, A., 2005: European abatement of surface ozone in a global perspective. Ambio, 34, 47-53.

Takigawa, M., Niwano, M., Akimoto, H., Takahashi, M., and Kobayashi, K., 2009: Projection of surface ozone over East Asia in 2020. Journal of Agricultural Meteorology, 65, 161166.

Teklic, T., Vrataric, M., Sudaric, A., Kovacevic, V., Vukadinovic, V., and Bertic, B., 2009: Relationships among chloroplast pigments concentration and chlorophyllmeter readings in soybean under influence of foliar magnesium application. Communications in Soil Science and Plant Analysis, 40, 706-725.

Thomas, V. F. D., Braun, S., and Flückiger, W., 2006: Effects of simultaneous ozone exposure and nitrogen loads on carbohydrate concentrations, biomass, growth, and nutrient concentrations of young beech trees (Fagus sylvatica). Environmental Pollution, 143, 341-354.

Uddling, J., Gelang-Alfredsson, J., Piikki, K., and Pleije, H., 2007: Evaluating the relationship between leaf chlorophyll concentration and SPAD-502 chlorophyll meter readings. Photosynthesis Research, 91, 37-46.

Von Willert, D. J., Eller, B. M., Werger, M. J. A., Brinckmann, E., and Ihlenfeldt, H. D., 1992: Life strategies of succulents in deserts, with special reference to the Namib desert. Cambridge University Press, Cambridge, UK, pp.368.
Wang, X. N., Qu, L., Mao, Q., Watanabe, M., Hoshika, Y., Koyama, A., Kawaguchi, K., Tamai, Y., and Koike, T., 2015: Ectomycorrhizal colonization and growth of the hybrid larch $\mathrm{F}_{1}$ under elevated $\mathrm{CO}_{2}$ and $\mathrm{O}_{3}$. Environmental Pollution, 197, $116-126$.

Watanabe, M., Kitaoka, S., Eguchi, N., Watanabe, Y., Satomura, T., Takagi, K., Satoh, F., and Koike, T., 2014: Photosynthetic traits and growth of Quercus mongolica var. crispula sprouts attacked by powdery mildew under free-air $\mathrm{CO}_{2}$ enrichment. European Journal of Forest Research, 133, 725-733.

Watanabe, M., Umemoto-Yamaguchi, M., Koike, T., and Izuta, T., 2010: Growth and photosynthetic response of Fagus crenata seedlings to ozone and /or elevated carbon dioxide. Landscape and Ecological Engineering, 6, 181-190.

Watanabe, M., Yamaguchi, M., Tabe, C., Iwasaki, M., Yamashita, R., Funada, R., Fukami, M., Matsumura, H., Kohno, Y., and Izuta, T., 2007: Influence of nitrogen load on the growth and photosynthetic responses of Quercus serrata seedlings to $\mathrm{O}_{3}$. Trees, 21, 421-432.

Watanabe, M., Yonekura, T., Honda, Y., Yoshidome, M., Nakaji, T., and Izuta, T., 2005: Effects of ozone and soil water stress, singly and in combination, on leaf antioxidative system of Fagus crenata seedlings. Journal of Agricultural Meteorology, 60, 1105-1108.

Winwood, J., Price, A. J., and Hanke, D. E., 2007: Effect of longterm free-air ozone fumigation on the cytokinin content of mature beech trees. Plant Biology, 9, 265-278.

Yachandra, V. K., DeRose, V. J., Latimer, M. J., Mukerji, I., Sauer, K., and Klein, M. P., 1993: Where plants make oxygen: a structural model for the photosynthetic oxygen-evolving manganese cluster. Science, 260, 675-679.

Yamaguchi, M., Watanabe, M., Matsumura, H., Kohno, Y., and Izuta, T., 2011: Experimental studies on the effects of ozone on growth and photosynthetic activity of Japanese forest tree species. Asian Journal of Atmospheric Environment, 5, 65-78.

Yamaji, K., Ohara, T., Uno, I., Tanimoto, H., Kurokawa, J., and Akimoto, H., 2006: Analysis of the seasonal variation of ozone in the boundary layer in East Asia using the Community Multiscale Air Quality model: What controls surface ozone levels over Japan?. Atmospheric Environment, 40, 1856-1868.

Yong, J. W. H., Wong, S. C., Letham, D. S., Hocart, C. H., and Farquhar, G. D., 2000: Effect of elevated $\mathrm{CO}_{2}$ and nitrogen nutrition on cytokinins in the xylem sap and leaves of cotton. Plant Physiology, 124, 767-780. 